\title{
Framework untuk Mendesain Sistem Massive Open Online Courses (MOOCs) untuk Universitas di Indonesia
}

\author{
Rio Guntur Utomo', Yusep Rosmansyah ${ }^{2}$ \\ 1) Teknologi Informasi, Fakultas Informatika, Universitas Telkom \\ Jl. Telekomunikasi No. 1, Bandung, Jawa Barat, Indonesia \\ Email: riogunturutomo@telkomuniversity.ac.id \\ 2) Sekolah Teknik Elektro dan Informatika, Institut Teknologi Bandung \\ Jl. Ganeca No. 10, Bandung, Jawa Barat, Indonesia \\ Email: yusep@stei.itb.ac.id
}

\begin{abstract}
ABSTRAK
Massive Open Online Courses (MOOCs) adalah model alternatif pembelajaran jarak jauh. MOOCs memberikan cara baru yang akan mengubah caranya pendidikan disampaikan dan dikonsumsi. Untuk melaksanakan MOOCs di Indonesia, diperlukan pedoman untuk menemukan desain sistem yang sesuai. Makalah ini menawarkan a kerangka kerja untuk merancang sistem MOOCs untuk universitas di Indonesia. Framework tersebut dirancang dengan menggunakan Design Science Research Methodology (DSRM) dan menggunakan model ADDIE sebagai dasar pengembangannya. Terakhir, framework yang telah dikembangkan akan menjadi acuan dasar merancang sistem MOOCs untuk universitas di Indonesia.
\end{abstract}

Kata kunci: moocs, pembelajaran jarak jauh, e-learning, framework

\begin{abstract}
Massive Open Online Courses (MOOCs) is an alternative model of distance learning. MOOCs provide a new way that will be change how education is delivered and consumed. To implement MOOCs in Indonesia, a guideline is needed to find the suitable system design. This paper offers a framework for designing MOOCs system for universities in Indonesia. The framework was designed using Design Science Research Methodology (DSRM) and using the ADDIE framework as the basis for its development. Finally, the developed framework will act as a base reference for designing MOOCs systems for universities in Indonesia.
\end{abstract}

Keywords: moocs, distance learning, e-learning, framework.

\section{Pendahuluan}

Pembelajaran jarak jauh adalah model pembelajaran yang di mana peserta didik dan pendidik terpisah jarak maupun waktu dan pembelajarannya menggunakan berbagai sumber belajar yang memanfaatkan teknologi komunikasi, informasi, dan media lainnya. Prinsip pembelajaran jarak jauh adalah kapanpun, dimanapun dan untuk siapa saja (Soekartowi, Haryono \& Librero, 2002). Hampir semua program pendidikan formal bisa dilakukan secara tatap muka melalui pembelajaran jarak jauh.

Pembelajaran jarak jauh memungkinkan pelajar untuk mendapatkan pengetahuan tanpa harus menghadiri kelas secara fisik (Soekartowi, Haryono \& Librero, 2002). Peserta didik bisa di satu tempat sementara guru dan pelajaran diikuti di tempat lain, di kota lain dan bahkan di negara lain. Interaksi bisa dijalankan secara on-line dan real-time atau off-line atau diarsipkan.

Massive Open Online Courses (MOOCs) adalah yang terbaru model pembelajaran jarak jauh. MOOCs menargetkan peserta dengan jumalah yang tidak terbatas dan membuka akses melalui situs web. Dalam praktiknya, di selain pembelajaran tradisional seperti video dan bacaan, MOOC menyediakan tempat interaksi antar pengguna untuk membantu buat komunitas untuk siswa, guru, dan pengajar asisten.

Di Indonesia sendiri, MOOCs belum menjadi pilihan utama seperti model pembelajaran jarak jauh lainnya. Namun, bukan tidak mungkin di MOOCs di masa depan akan diterapkan di Indonesia (Utomo \& Rosmansyah, 2014). Studi ini akan mengembangkan kerangka kerja atau framework untuk merancang sistem MOOCs untuk universitas di Indonesia. 
Menggunakan layanan komputer dan jaringan lokal yang digabungkan dengan internet, proses pembelajaran dapat diakses di cara fleksibel. Ini membantu dalam mengakses materi pembelajaran dan juga berkomunikasi. Dengan internet sebagai fasilitas utama pembelajaran jarak jauh yang belum menjadi masalah, masalah utama pembelajaran jarak jauh adalah jenis sistem pembelajaran yang cocok untuk Indonesia.

Tujuan dari penelitian ini adalah untuk mengembangkan sebuah kerangka kerja sistem MOOCs yang sesuai dengan pendidikan di Indonesia. Hasil penelitian ini dapat membantu merancang sistem MOOCs jika praktisi pendidikan ingin menerapkannya di Indonesia.

\section{Latar Belakang Teori}

\subsection{Peta Literatur}

Peta literatur merupakan grafik yang membantu untuk memvisualisasikan hubungan antar karya tulis. Pemetaan membantu mengidentifikasi masalah seperti koneksi dan kedekatan ide dan temuan. Peta literatur berguna karena membantu membagi makalah menjadi beberapa bagian atau bab. Gambar 1 menunjukkan peta literatur penelitian MOOCs.

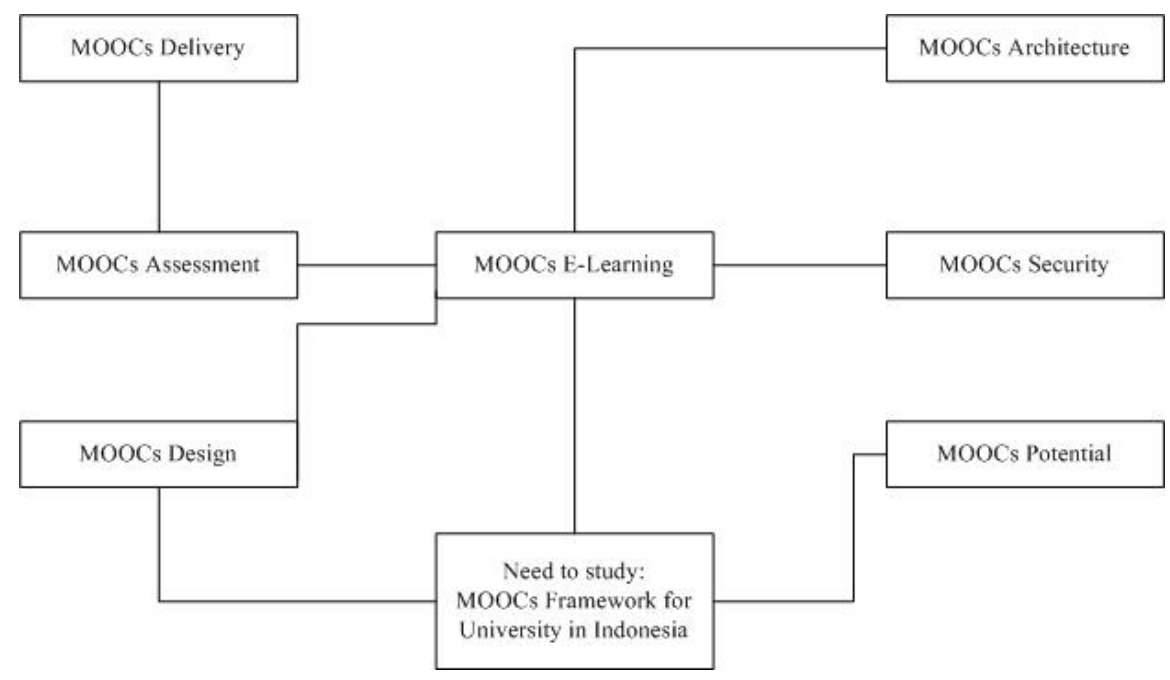

Gambar 1. Peta literatur penelitian MOOCs

Seperti yang ditunjukkan pada gambar 1, beberapa penelitian tentang MOOCs telah dilakukan. Seperti yang dilakukan oleh Daradoumis et al (2013). yang mengusulkan framework yang bertujuan untuk meningkatkan manajemen, pengiriman, dan evaluasi efisiensi MOOCs di tingkat dasar individu. Subbian (2013) pada studinya juga meneliti potensi $M O O C s$ dalam meningkatkan pengalaman belajar dan memfasilitasi pendidikan interdisipliner di bidang STEM. Kay et al (2013), menyatakan bahwa kursus online terbuka besarbesaran telah meledak, menjanjikan untuk memuaskan dahaga di seluruh dunia akan pendidikan yang berkualitas tinggi, dipersonalisasi, dan gratis.

Dari hasil review tersebut, rangkuman hasil penelitian-penelitan tersebut bisa disimpulkan bahwa MOOCs memiliki potensi dalam meningkatkan pengalaman belajar dan memfasilitasi pendidikan interdisipliner, juga MOOCs dapat menjanjikan untuk memenuhi kebutuhan akan pendidikan yang berkualitas tinggi, dipersonalisasi, dan gratis.

Mengenai implementasi pembelajaran jarak jauh yang sangat berbeda di negara manapun, belum ada penelitian yang mengembangkan framework untuk merancang sistem MOOCs khususnya untuk universitas di Indonesia. Oleh karena itu, studi ini diperlukan untuk mengembangkan kerangka kerja perancangan sistem MOOCs di Indonesia.

\subsection{Instructional System Design}

Dasar untuk mengembangkan framework ini menggunakan Instructional System Design. Instructional System Design yang akan digunakan adalah $A D D I E$. Model ADDIE adalah framework yang memiliki proses umum yang digunakan oleh desainer instruksional dan pengembang pelatihan (Peterson, 2003). Ini merupakan pedoman untuk membangun pelatihan yang efektif dan alat pendukung kinerja dalam lima tahap yaitu 
analisis, desain, pengembangan, implementasi, evaluasi. ADDIE umumnya digunakan untuk desain pembelajaran secara keseluruhan dalam sistem pendidikan konvensional.

\subsection{Connectivism Theory}

Connectivism adalah teori yang menyatakan bahwa pengetahuan didistribusikan ke seluruh jaringan koneksi, dan oleh karena itu pembelajaran terdiri dari kemampuan untuk membangun dan melintasi jaringan tersebut. Ini berbagi dengan beberapa teori lain proposisi inti, bahwa pengetahuan tidak diperoleh, seolah-olah itu adalah benda. Pengetahuan, dalam teori ini, secara harfiah adalah kumpulan koneksi yang dibentuk oleh tindakan dan pengalaman (Baker, 2012).

\section{Metode Penelitian}

Metodologi penelitian yang akan digunakan untuk merancang kerangka kerja tersebut adalah Design Science Research Methodology (DSRM) yang dikemukakan oleh Peffers et al. (2008) seperti yang ditunjukkan pada gambar 2. Enam kegiatan DSRM untuk mencapai hasil penelitian didefinisikan sebagai berikut:

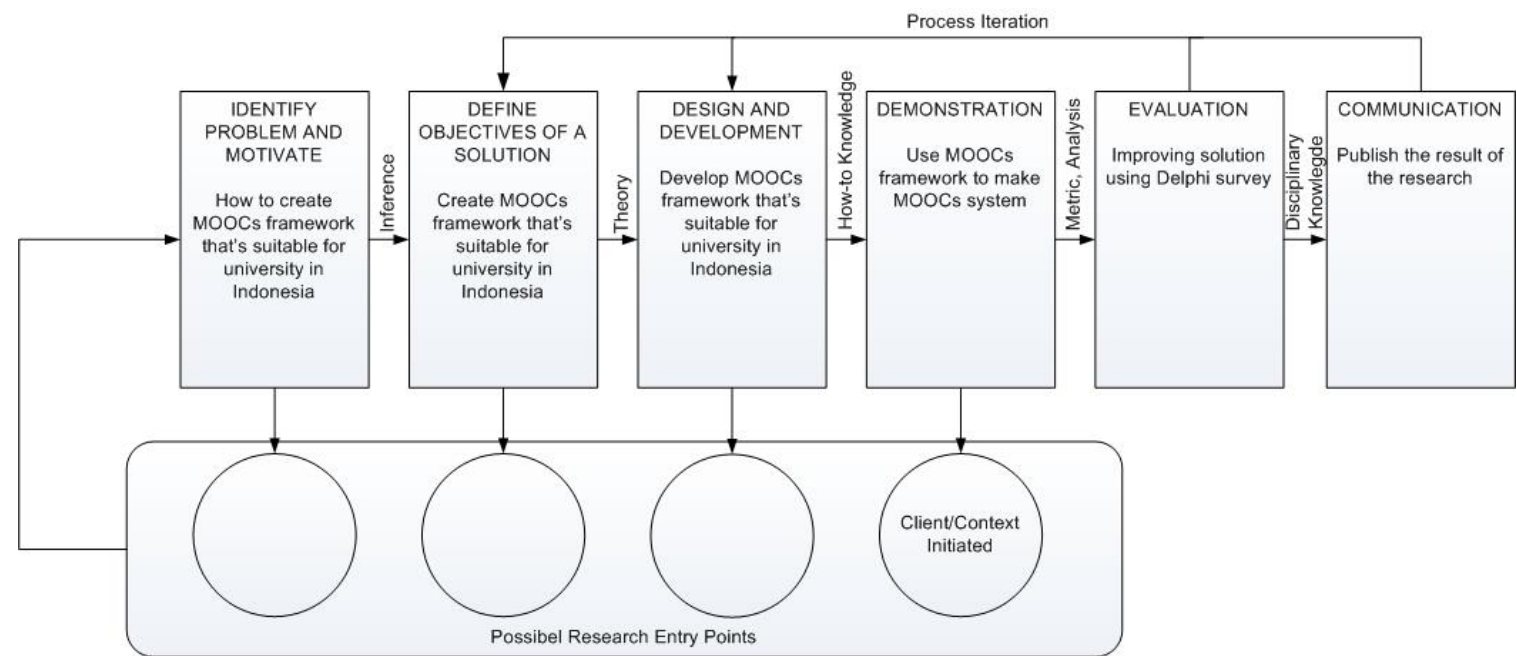

Gambar 2. Metode DSRM

\subsection{Identify Problem \& Motivate}

Tindakan ini dimulai dengan memahami permasalahan di lapangan untuk menentukan solusi yang akan dihasilkan lebih lanjut dalam penelitian ini. Penelitian ini bertujuan untuk mengembangkan framework sistem MOOCs yang sesuai dengan pendidikan di Indonesia. Keberadaan masalah dibedakan dari literatur yang ada dan penelitian-penelitian sebelumnya.

\subsection{Define Objectives of a Solution}

Setelah memperjelas masalah, sebuah hipotesis utilitas dibentuk, yang bertujuan menyarankan desain-meta untuk masalah tersebut didefinisikan dalam aktifitas ini. Pada tahap ini tujuan penelitian ditentukan untuk mengembangkan framework untuk MOOCs.

\subsection{Design \& Development}

Pada tahap ini dirancang framework dengan menggunakan informasi yang diperoleh dari studi pustaka pembelajaran jarak jauh dan e-learning.

\subsection{Demonstration}


Setelah desain dan pengembangan, hasil dari langkah sebelumnya akan digunakan dalam langkah ini untuk mengembangkan framework.

\subsection{Evaluation}

Kerangka yang telah dikembangkan akan dievaluasi dengan metode pengujian framework.

\subsection{Communication}

Penyampaian kemajuan penelitian, hasil dan kesimpulan ditulis dalam bentuk laporan. Laporan penelitian disiapkan dalam bentuk publikasi artikel.

\section{Hasil dan Pembahasan}

Fokus penelitian adalah studi $M O O C s$, teori dan konsep pembelajaran jarak jauh. Dengan internet sebagai fasilitas utama pembelajaran jarak jauh yang belum menjadi masalah, maka permasalahan utama pembelajaran jarak jauh adalah seperti apa sistem pembelajaran yang cocok untuk Indonesia. Dan untuk mengatasi masalah tersebut, penelitian ini bertujuan untuk mengembangkan framework sistem MOOCs yang sesuai dengan pendidikan di Indonesia.

\subsection{Pengembangan Framework}

Alur kegiatan framework yang merupakan pengembangan dari model $A D D I E$ dijelaskan sebagai berikut:

\subsubsection{Analysis}

Dalam tahap analisis, motivasi dan tujuan pembelajaran ditentukan. Juga dalam fase ini, batasan dan kondisi sistem juga ditentukan. Pada tahap ini dilakukan aktifitas sebagai berikut:

a. Tujuan pembelajaran dan motivasi memegang peranan penting, karena dengan memperhatikan motivasi peserta didik, seperti keinginan untuk memperluas ilmunya, menjadi spesialis, dan lain-lain. Oleh karena itu desain sistem harus menyesuaikan dengan ini.

b. Untuk memudahkan motivasi peserta didik, maka sistem yang akan dibuat akan menerapkan klasifikasi materi yang disajikan. Klasifikasi ini berguna agar peserta didik dapat menyesuaikan materi yang ditangkap dengan tujuan peserta didik itu sendiri. Tabel 1 menyajikan rangkuman untuk klasifikasi dari materi pembelajaran.

Tabel 1. Klasifikasi materi pembelajaran

\begin{tabular}{|l|l|}
\hline Klasifikasi & Keterangan \\
\hline Pemula & $\begin{array}{l}\text { Materi yang disajikan cocok untuk pemula yang baru mengetahui ide } \\
\text { dasar pelajaran atau tidak sama sekali. }\end{array}$ \\
\hline Lanjut & $\begin{array}{l}\text { Materi yang disajikan cocok untuk tingkat lanjut yang telah } \\
\text { menguasai dasar-dasar mata pelajaran atau telah menyelesaikan } \\
\text { tingkat dasar. }\end{array}$ \\
\hline Mahir & $\begin{array}{l}\text { Materi yang disajikan cocok untuk tingkat mahir yang telah } \\
\text { menguasai pengajaran tingkat lanjut atau telah menyelesaikan tingkat } \\
\text { lanjut. }\end{array}$ \\
\hline
\end{tabular}

c. Analisis materi yang akan disajikan secara online juga perlu dilakukan. Ini untuk menilai apakah suatu materi cocok atau tidak jika diberikan secara online [9]. Sebab, ada beberapa mata pelajaran yang dikategorikan sulit untuk disajikan secara online, seperti mata pelajaran yang memerlukan aktifitas berbicara atau menyimak [10].

d. Batasan dan kondisi yang dapat mempengaruhi sistem juga dianalisis. Di Indonesia terdapat beberapa keterbatasan dan kondisi yang menjadi kendala dalam melakukan pembelajaran online [11]. Beberapa di antaranya seperti sumber daya manusia, infrastruktur, dan implementasi yang dirangkum pada Tabel 2. 
Tabel 2. Batasan dan kondisi sistem

\begin{tabular}{|l|l|}
\hline \multicolumn{1}{|c|}{ Batasan } & \multicolumn{1}{|c|}{ Kondisi } \\
\hline Sumber Daya Manusia & $\begin{array}{l}\text { Pelajar di Indonesia tidak semuanya paham akan teknologi. Ini dapat } \\
\text { mempengaruhi pembelajaran online. Sebab, jika peserta didik tidak mengetahui } \\
\text { cara menggunakan sistem maka akan sulit mengikuti pembelajaran online. } \\
\text { Bisa juga dengan dosen. Para dosen umumnya belum terlalu paham dengan } \\
\text { pembelajaran online. Penyampaian materi secara online berbeda dengan } \\
\text { penyampaian materi secara langsung. }\end{array}$ \\
\hline Infrastruktur & $\begin{array}{l}\text { Kecepatan internet di Indonesia masih terbilang lambat. Hal tersebut dapat } \\
\text { menghambat proses pembelajaran online, apalagi jika membutuhkan kecepatan } \\
\text { bandwidth yang tinggi seperti penggunaan audio dan video dalam proses } \\
\text { pembelajaran. } \\
\text { Biaya membangun server cukup mahal. Ini terdiri dari biaya penyimpanan } \\
\text { untuk menyimpan bahan ajar seperti video, audio, dan lain-lain. Selain itu, } \\
\text { biaya lain yang juga termasuk adalah biaya penyediaan akses ke server atau } \\
\text { biaya bandwidth. }\end{array}$ \\
\hline Implementasi & $\begin{array}{l}\text { Untuk implementasi, kondisi yang terjadi adalah karena terhambatnya } \\
\text { implementasi selain SDM dan infrastruktur, hambatan lainnya adalah memilih } \\
\text { model yang sesuai untuk diimplementasikan. Beberapa model yang dapat } \\
\text { dipilih dalam pelaksanaannya adalah suplemen, pelengkap, dan substitusi. }\end{array}$ \\
\hline
\end{tabular}

Untuk mengatasi permasalahan diatas, solusi yang dapat ditawarkan dapat dilihat pada Tabel 3 berikut.

Tabel 3. Solusi untuk batasan dan kondisi

\begin{tabular}{|l|l|}
\hline \multicolumn{1}{|c|}{ Batasan } & \multicolumn{1}{c|}{ Solusi } \\
\hline Sumber Daya & $\begin{array}{l}\text { Untuk mengatasi masalah pemanfaatan teknologi baru bagi peserta didik dan } \\
\text { dosen, diperlukan suatu panduan. } \\
\text { Bagi peserta didik, pedoman yang dapat dibuat dalam bentuk tutorial online } \\
\text { tentang cara penggunaan sistem mulai dari awal hingga proses pembelajaran. } \\
\text { Bagi dosen dapat dibuatkan panduan online tentang cara membuat bahan ajar } \\
\text { online dan juga mempraktikkan berbagai pendekatan cara mengajar secara } \\
\text { online. }\end{array}$ \\
\hline Infrastruktur & $\begin{array}{l}\text { Untuk mengatasi masalah kecepatan tinggi, maka penggunaan media video dan } \\
\text { audio pembelajaran, ukuran file yang digunakan tidak terlalu besar dan durasinya } \\
\text { tidak terlalu lama. } \\
\text { Sedangkan untuk mengatasi mahalnya biaya pembangunan server, untuk } \\
\text { penyimpanan file dapat dilakukan dengan menggunakan pihak ketiga. }\end{array}$ \\
\hline Implementasi & $\begin{array}{l}\text { Untuk implementasinya sendiri, karena beberapa kendala yang terjadi, maka } \\
\text { model yang paling cocok jika diimplementasikan adalah model suplemen. Siswa } \\
\text { memiliki kebebasan untuk memilih, apakah akan memanfaatkan materi } \\
\text { elektronik atau tidak. Dalam hal ini, tidak ada kewajiban / keharusan bagi peserta } \\
\text { didik untuk mengakses materi elektronik. Meski sifatnya sebagai pilihan, namun } \\
\text { siswa yang memanfaatkannya akan memiliki tambahan ilmu atau wawasan. Ini } \\
\text { sesuai dengan tujuan MOOCs. }\end{array}$ \\
\hline
\end{tabular}

\subsubsection{Design}

Hasil analisis pada tahap sebelumnya digunakan. Hasil analisis tujuan, motivasi, kendala, batasan dan kondisi akan digunakan untuk memilih desain yang sesuai. Pada tahap ini dilakukan kegiatan sebagai berikut:

a. Desain tersebut akan memfasilitasi prinsip pembelajaran jarak jauh. Prinsip-prinsipnya adalah pembelajaran harus mempunyai tujuan yang jelas, peserta didik harus terlibat secara aktif, 
pembelajaran harus menggunakan berbagai media, lingkungan belajar harus mencakup pembelajaran berbasis masalah serta berbasis pengetahuan, pengalaman belajar harus mendukung interaksi dan pengembangan komunitas masyarakat. minat, dan praktik pembelajaran jarak jauh berkontribusi pada misi sosial yang lebih besar dari pendidikan dan pelatihan dalam masyarakat.

b. Dari hasil analisis tersebut, pembelajaran bertujuan untuk menularkan ilmu dari dosen kepada peserta didik. Oleh karena itu, model $x M O O C s$ merupakan desain yang paling cocok untuk digunakan. Pada model $x M O O C s$, hasil pembelajaran merupakan dari transmisi informasi dari seorang ahli kepada pemula, sedangkan pada model lainnya yaitu $c M O O C s$, hasil pembelajaran merupakan dari berbagi pengetahuan antar peserta. Beberapa fitur desain dari model tersebut adalah perangkat lunak platform yang dirancang khusus, video perkuliahan, materi pendukung dan ruang diskusi / komentar bersama.

c. Selain fitur model, tutorial harus disediakan untuk pelajar dan dosen. Tutorial diperlukan agar mereka dapat beradaptasi dengan baik pada sistem sebelum mereka menggunakannya untuk proses pembelajaran.

\subsubsection{Development}

Setelah desain, tahap selanjutnya adalah pengembangan. Pada tahap ini dikembangkan sistem sesuai dengan desain yang telah dibuat. Elemen $x M O O C$ s digunakan untuk menjadi bagian dari pengembangan. Pada tahap ini dilakukan kegiatan sebagai berikut:

a. Karena desain yang dipilih adalah $x M O O C s$, beberapa fitur yang perlu dikembangkan adalah tugas yang dinilai oleh komputer, penilaian sejawat, moderasi diskusi tanpa atau sangat ringan, serta lencana atau sertifikat. Tugas dan penilaian adalah proses belajar. Dan diskusi dan lencana atau sertifikat adalah fitur dari $x$ MOOCs.

b. Dalam proses pengembangan juga diperhatikan ruang untuk menyimpan materi pembelajaran. Bahan ajar yang akan disimpan adalah video, audio, dan file lainnya.

Tahapan setiap kursus juga ditentukan. Mulai dari mendaftar, mengikuti kursus, mengerjakan tugas, diskusi, penilaian dan terakhir mendapatkan sertifikat.

\subsubsection{Implementation}

Pada tahap implementasi, diperlukan implementasi elemen $x M O O C s$ yang secara teknis dapat menjadi perwujudan desain dan pengembangan. Pada tahap ini dilakukan kegiatan sebagai berikut:

a. Pihak ketiga akan digunakan sebagai server untuk penyimpanan media sistem pembelajaran online. Dan tidak menutup kemungkinan untuk menggunakan lebih dari satu pihak ketiga sebagai server.

b. Pelaksanaan xMOOCs akan digunakan sebagai suplemen untuk kursus tradisional. Jadi materi yang diberikan mungkin tidak sama seperti kurikulum atau silabus. Itu tergantung pada tujuan pembelajaran.

c. Proses dari mendaftar; mengikuti kursus, mengerjakan tugas, diskusi, penilaian, dan mendapatkan sertifikat adalah bagian dari implementasi proses pembelajaran xMOOCs.

\subsubsection{Evaluation}

Sistem xMOOCs yang telah diimplementasikan akan dievaluasi pada tahap evaluasi ini. Evaluasi ini mencakup apakah tahapan pelaksanaan sudah sesuai dengan yang diharapkan. Evaluasi terdiri dari dua bentuk, evaluasi formatif dan sumatif. Evaluasi formatif bertujuan untuk melihat apakah pada setiap tahapan proses sudah sesuai dengan yang diharapkan. Evaluasi sumatif bertujuan untuk melihat apakah hasil akhir sudah sesuai dengan harapan dan sesuai dengan tujuan pembelajaran.

Untuk melihat secara integral dari kerangka yang diusulkan, maka dirancanglah kerangka pemahaman yang menggambarkan lokasi setiap tahapan kegiatan yang terdapat pada gambar 3: 


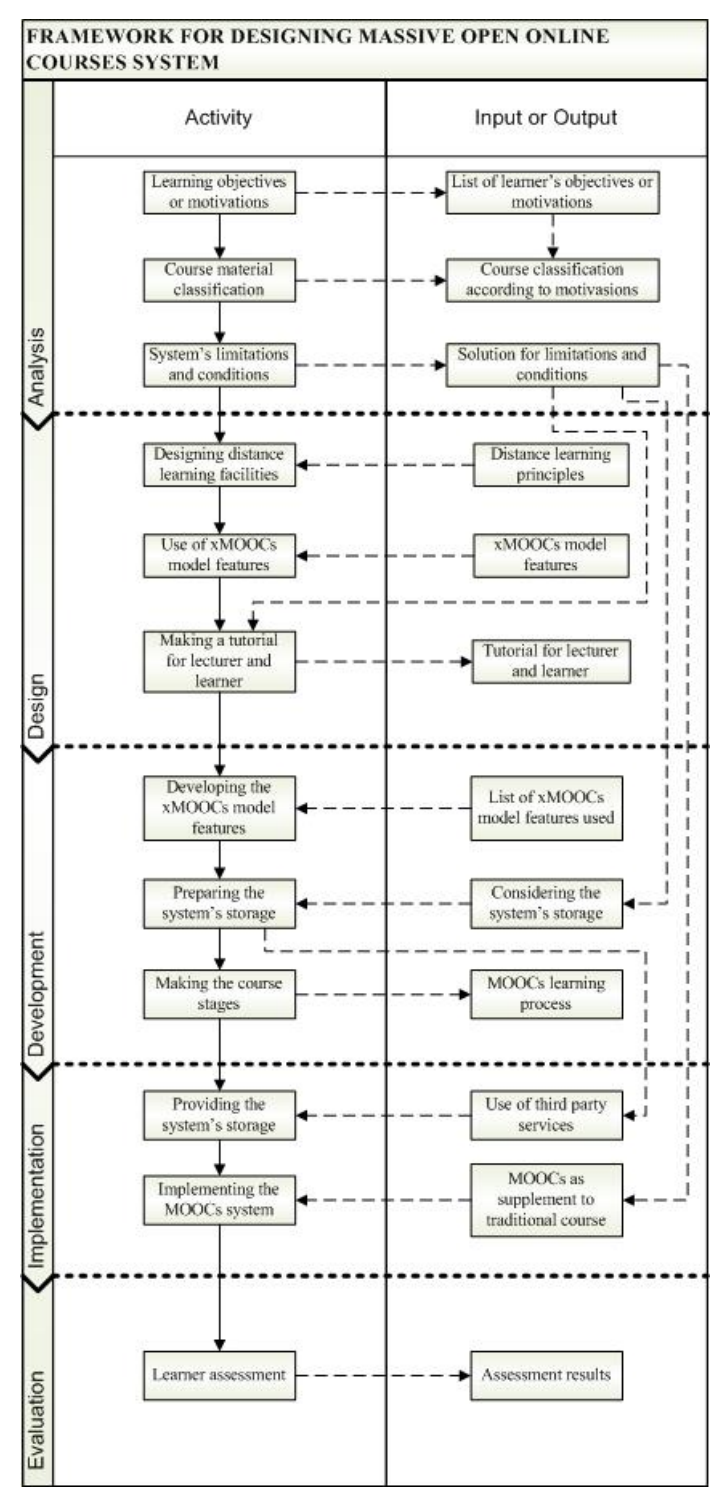

Gambar 3. Alur proses dari framework MOOCs yang diusulkan

Selanjutnya, gambar 4 menyajikan framework MOOCs yang telah dikembangkan.

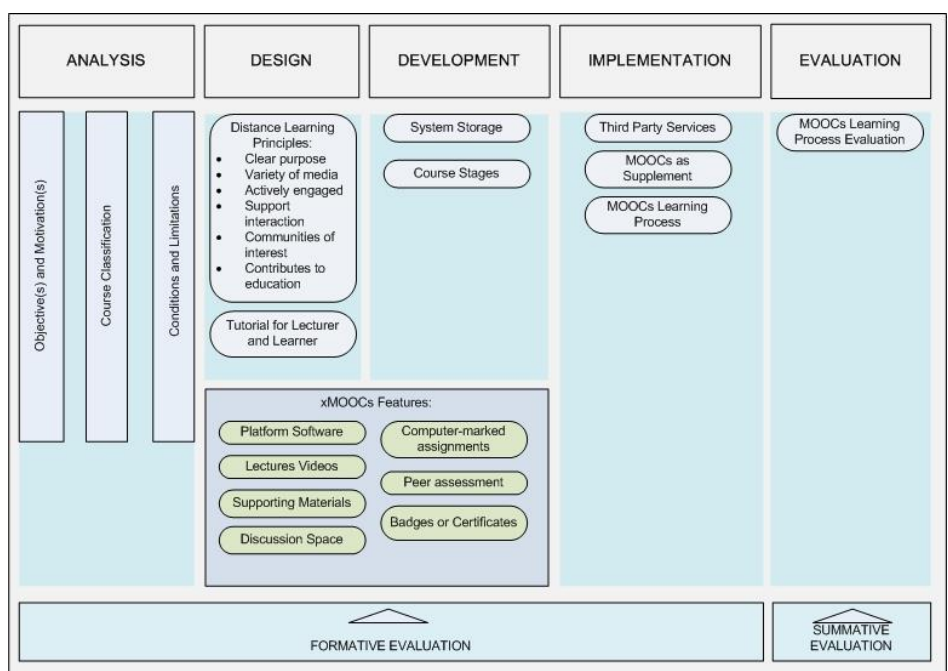

Gambar 4. Framework MOOCs yang diusulkan 


\subsection{Evaluasi Framework}

Tahap evaluasi adalah untuk memperbaiki desain kerangka yang diusulkan. Evaluasi konten framework itu sendiri dilakukan dengan metode Delphi.

Dalam evaluasi ini, sebanyak 4 orang ahli yang memiliki pengalaman di bidang pembelajaran dan atau pembelajaran jarak jauh / e-learning dikonsultasi tentang masukan yang dibutuhkan. Dalam survei Delphi ini, para ahli diminta beberapa hal untuk dipertimbangkan yang disajikan pada Tabel 4 berikut.

Tabel 4. Hasil dan kesimpulan dari kuesioner Delphi

\begin{tabular}{|c|c|c|}
\hline No & Questions & Results \\
\hline 1 & $\begin{array}{l}\text { Pengembangan sistem pembelajaran jarak } \\
\text { jauh harus sesuai dengan tujuan dan } \\
\text { motivasi peserta didik }\end{array}$ & $\begin{array}{l}\text { Semua ahli setuju akan hal } \\
\text { ini }\end{array}$ \\
\hline 2 & $\begin{array}{l}\text { Interaktivitas dalam pembelajaran jarak } \\
\text { jauh itu penting }\end{array}$ & $\begin{array}{l}\text { Semua ahli setuju akan hal } \\
\text { ini }\end{array}$ \\
\hline 3 & $\begin{array}{l}\text { mbelajaran jarak jauh perlu menggunakan } \\
\text { rbagai macam media dalam proses } \\
\text { mbelajaran }\end{array}$ & $\begin{array}{l}\text { Semua ahli setuju akan hal } \\
\text { ini }\end{array}$ \\
\hline 4 & $\begin{array}{l}\text { elajaran jarak jauh di Indonesia } \\
\text { angkan dengan memperhatikan } \\
\text { eterbatasan di Indonesia }\end{array}$ & $\begin{array}{l}\text { nyakan ahli setuju akan } \\
\text { i }\end{array}$ \\
\hline 5 & $\begin{array}{l}\text { di Indonesia } \\
\text { pelaksanaan }\end{array}$ & ang \\
\hline 6 & $\begin{array}{l}\text { ya manusia di Indonesia } \\
\text { dala dalam pelaksanaan } \\
\text { jauh }\end{array}$ & $\operatorname{tang}$ \\
\hline 7 & $\begin{array}{l}\text { internet di Indonesia masih menjadi } \\
\text { dalam penerapan pembelajaran } \\
\text { uh }\end{array}$ & setuju akan \\
\hline 8 & $\begin{array}{l}\text { Perlu diberikan panduan bagaimana } \\
\text { penggunaan sistem pembelajaran jarak jauh } \\
\text { pada saat implementasi }\end{array}$ & i setuju akan \\
\hline 9 & $\begin{array}{l}\text { Penggunaan pihak ketiga (Youtube, Vimeo, } \\
\text { Google Drive, dll.) Dapat menjadi alternatif } \\
\text { solusi permasalahan infrastruktur internet } \\
\text { dan implementasi pembelajaran jarak jauh di } \\
\text { Indonesia. }\end{array}$ & $\begin{array}{l}\text { nyakan ahli setuju akan } \\
\text { i }\end{array}$ \\
\hline 10 & $\begin{array}{l}\text { Pembelajaran jarak jauh lebih cocok } \\
\text { digunakan sebagai pelengkap (tambahan) } \\
\text { pada kelas konvensional daripada sebagai } \\
\text { pengganti }\end{array}$ & $\begin{array}{l}\text { uju tentang } \\
\text { k setuju }\end{array}$ \\
\hline 11 & $\begin{array}{l}\text { Penilaian diperlukan sebagai hasil evaluasi } \\
\text { proses pembelajaran }\end{array}$ & i \\
\hline 12 & $\begin{array}{l}\text { Pemberian sertifikat digital diperlukan } \\
\text { sebagai bukti telah menyelesaikan kelas } \\
\text { pembelajaran jarak jauh }\end{array}$ & $\begin{array}{l}\text { Semua ahli setuju akan hal } \\
\text { ini }\end{array}$ \\
\hline
\end{tabular}

Hasil survei memberikan kesimpulan dan rekomendasi sebagai berikut:

1. Dosen berperan sebagai fasilitator, untuk mengimplementasikan e-learning, pengembang konten pembelajaran, desainer model pembelajaran, dan hal-hal lain yang berkaitan dengan pembelajaran berbasis multimedia yang dapat mendukung penerapan e-learning

2. Dosen memiliki peran sentral dan dapat menentukan keberhasilan penerapan e-learning

3. Dibutuhkan IT Teknis yang baik untuk dapat merancang aplikasi sistem yang handal, tanpa ada kendala teknis 
4. Kemampuan pedagogik, yaitu mampu merancang aplikasi e-learning dengan memperhatikan: teori pembelajaran, pendekatan pembelajaran (aspek psikologis), prinsip belajar, dll.

5. Perlu adanya kebijakan yang menyeluruh dari pelaksanaan pembelajaran jarak jauh, dilaksanakan dengan sungguh-sungguh, baik oleh dosen, mahasiswa maupun stakeholders.

6. Alat yang mudah dipahami baik oleh dosen maupun peserta, buku pedoman yang jelas, serta sarana dan prasarana yang telah disiapkan serta mendukung.

\section{Simpulan}

Sistem MOOCs telah diusulkan sebagai model pembelajaran jarak jauh yang baru. Namun, masih perlu menemukan MOOCs yang cocok untuk Indonesia. Karena, penerapan pembelajaran jarak jauh mungkin berbeda di setiap negara. Untuk mengatasi masalah ini, diusulkan suatu kerangka kerja untuk merancang sistem MOOCs yang sesuai khususnya untuk universitas di Indonesia.

Persyaratan untuk merancang kerangka kerja dapat dianalisis melalui studi literatur dan membandingkan kerangka lainnya. Selain itu, penelitian-penelitian sebelumnya juga perlu dipelajari. Untuk merancang kerangka kerja, disarankan untuk mengembangkan dari kerangka yang sudah ada. Dalam studi ini desain kerangka kerja MOOCs yang diusulkan dikembangkan dari ADDIE. Kerangka yang diusulkan terdiri dari prinsip pembelajaran jarak jauh dan proses dari tahap analisis hingga evaluasi. Melalui survei Delphi, kerangka yang diusulkan dievaluasi sehingga dapat ditingkatkan dan disesuaikan dengan kebutuhan pembelajaran jarak jauh di Indonesia.

\section{Daftar Pustaka}

1. Baker, T.J., 2012., Connectivism \& Connected Knowledge.

2. Daradoumis, T., Bassi, R., Xhafa, F., Caballe, S., 2013, A review on massive e-learning (MOOCs) design, delivery and assessment, P2P, Parallel, Grid, Cloud and Internet Computing (3PGCIC), 2013 Eighth International Conference on , vol., no., pp.208,213, 28-30 Oct. 2013

3. Kay, J., Reimann, P., Diebold, E., Kummerfeld, B., ,2013, MOOCs: so many learners, so much potential ..., Intelligent Systems, IEEE , vol.28, no.3, pp.70,77, May-June 2013

4. Peffers, K., Tuunanen, T., Rothenberger, M. A., Chatterjee, S., 2007, A design science research methodology for informat ion systems research, J. Manag. Inf. Syst., vol. 24, pp. 45-77, 2007.

5. Peterson, C., 2003, Bringing ADDIE to life: instructional design at its best, J. Educ. Multimed. Hypermedia, vol. 12, pp. 227-241, 2003.

6. Subbian, V., 2013, Role of MOOCs in integrated STEM education: A learning perspective, Integrated STEM Education Conference (ISEC), 2013 IEEE, vol., no., pp.1,4, 9-9 March 2013

7. Soekartawi., Haryono, A., Librero, F., 2002, Greater learning opportunities through distance education: experiences in Indonesia and the philippines, Journal of Southeast Asian Education, Vol. 3, No. 2, pp. 283-320, 2002.

8. Utomo, R.G., Rosmansyah, Y., 2014, MOOCs as an alternative to distance learning model for University in Indonesia, 2014 International Conference on ICT For Smart Society (ICISS), Bandung, 2014, pp. 182-184, doi: 10.1109/ICTSS.2014.7013170.

9. Firmansyah, F.H., Sari, I.P., Musyarofah., 2019, PengembanganMedia Pembelajaran Interaktif Berbasis Android Untuk Pembelajaran Terbuka dan Jarak Jauh di Universitas Pendidikan Indonesia, Jurnal Pendidikan Multimediap Vol. 1, No. 2(2019), pp. 99-108.

10. Sylviani, S., Permana, F.C., Utomo, R.G., 2020, PHET Simulation sebagai Alat Bantu Siswa Sekolah Dasar dalam Proses Belajar Mengajar Mata Pelajaran Matematika, Jurnal Pendidikan Multimedia Vol. 2, No. 1(2020), pp. 1-10 
11. Prasetya, R., Setiawan, H.S., 2019, Pengembangan Ketersediaan Informasi Akademik Sekolah Menengah Atas DKI Jakarta Berbasis Web, Jurnal Pendidikan Multimedia 1, No. 1 (2019), pp. $9-18$ 